\title{
Pt decorated amorphous RuIr alloys as high efficiency electrocatalyst for methanol oxidation
}

\author{
Y. J. Ma, H. Wang, S. Ji, B. G. Pollet and R. F. Wang
}

\begin{abstract}
This study focuses primarily on improving the utilization and activity of anodic catalysts for methanol electro-oxidation. The Direct Methanol Fuel Cell (DMFC) anodic catalyst, a carbon supported Pt decorated amorphous RuIr nanoparticles catalyst (Pt@RuIr/C) was prepared by a two-step reduction method. The structure of Pt@RuIr/C nanoparticles was confirmed by Transmission Electron Microscopy (TEM) and X-ray Diffraction (XRD). The Pt@RuIr electrocatalysts exhibited good uniformity in distribution. Cyclic Voltammetry experiments showed that under the same quality of noble-metal, the Pt@RuIr/C catalyst had higher activity than the PtRuIr/C catalyst for methanol oxidation. It was also shown that the as-prepared structure of the Pt decorated amorphous RuIr alloys could obviously decrease the usage of noble-metal and enhance its catalytic activity at the same time.
\end{abstract}

\section{Introduction}

Direct Methanol Fuel Cells (DMFCs) are widely considered as highly efficient, high energy density, easy handling and distribution of liquid fuel, and clean energy sources ${ }^{1}$. Currently, the high cost, unsatisfactory activity and durability of Pt-based catalysts are the major challenges that hinder commercialisation of $\mathrm{DMFCs}^{2}$. Currently PtRu alloy is the most promising electrocatalyst for methanol electro-oxidation, due to the ability of $\mathrm{Ru}$ in the alloy to promote fast oxidation of $\mathrm{CO}^{3}$.

Despite the promising activity of the PtRu alloy, further improvement in activity and durability is still necessary for practical applications of DMFCs. The introduction of a third metal is a promising approach to develop novel methanol-oxidation catalysts with improved performance. Iridium, in the form of iridium-platinum (IrPt) alloys, is a promising alloying material for applications in various fuel cell catalysts. It has been reported to be active for ethanol oxidation and Oxygen Reduction Reaction (ORR) ${ }^{4,5}$. At the same time, it is less expensive than $\mathrm{Pt}$ and $\mathrm{Ru}$, and can be easily synthesized with small particle sizes $(\leq 2 \mathrm{~nm})$. However, if iridium has to be used in fuel cell catalysts, it is likely that, due to its lower availability on earth than platinum, it will become more expensive in the future. Ir-Pt alloy is also electrochemically stable in acidic media. Among the ternary alloy catalysts, the PtRuIr/C system seems to be a promising catalyst for DMFCs ${ }^{6-8}$. 
However, these Pt-based alloy catalysts are not satisfactory to lower the Pt loading enough to meet the requirements of commercializing DMFCs.

A reasonable approach for minimizing the Pt content without sacrificing electrocatalytic activity of the electrocatalysts is to form core/shell structures via surface modification of the metal or alloys nanoparticles. ${ }^{9-1}$ In this way precious or active metals (Pt or $\mathrm{Pt}$ alloys) are deposited on cost-effective or inactive metal/alloy nanoparticles so that the utilization of Pt can be further improved.

Recently, amorphous metal catalysts with long-range disordering and short-range ordering have attracted a lot of attention due to their unique isotropic structure. Compared with their crystalline counterparts, amorphous catalysts have a higher concentration of coordinated unsaturated sites on their surface ${ }^{12}$. There are a few reports on employing amorphous metal as the core or shell in core-shell structured nanoparticles ${ }^{13,14}$. For example, carbon-supported Fe@Pt core-shell catalysts with Fe cores in different crystal states were synthesized, in contrast to its crystallized counterparts, the iron in the amorphous state shows a distinct and powerful ability as a core for the Fe@Pt nanoparticles. However, these amorphous Pt-contenting catalysts were prepared via mechanical alloying technique and the resulted alloys were micro particles.

This study aims to improve the Pt utilization rate and activity of anodic catalysts for methanol electrooxidation by synthesizing amorphous nano-sized Pt-based electrocatalyst. In this work, Pt@RuIr/C was prepared by a two-step reduction method. The structure of Pt-RuIr/C nanoparticles was confirmed by TEM and XRD. With the same Pt loading, the Pt@RuIr/C amorphous nanoparticle exhibited higher activity than the crystal PtRuIr/C nanoparticles for methanol oxidation. The structure of Pt decorated amorphous RuIr alloys can obviously decrease the utilization of noble-metal and enhance its catalytic activity at the same time.

\section{Experimental}

\section{Preparation of Pt@RuIr/C catalyst}

Pt@RuIr /C catalyst was prepared by a two-step reduction method. The detail procedure was as follows: $1.99 \mathrm{~mL}$ of $20 \mathrm{mg} \mathrm{mL} \mathrm{RuCl}_{3}, 2.56 \mathrm{~mL}^{-1}$ of $10 \mathrm{mg} \mathrm{mL}^{-1} \mathrm{H}_{2} \mathrm{IrCl}_{6}$ and sodium citrate (166 mg) were dissolved in $30 \mathrm{~mL}$ Ethylene Glycol (EG) and stirred for $0.5 \mathrm{~h}$. Pretreated carbon black Vulcan $\mathbb{R}$ XC72R (100 mg) was added to the mixture under stirring conditions. The $\mathrm{pH}$ of the system was adjusted to $\sim 9$ by adding $5 \mathrm{wt} \% \mathrm{KOH} / \mathrm{EG}$ solution under vigorous stirring. The mixture was then placed into a flask and the temperature was maintained at $160^{\circ} \mathrm{C}$ for $6 \mathrm{~h}$. The as-prepared catalyst was collected by filtration, rinsed with deionized water for 5 times and dried in air at $60^{\circ} \mathrm{C}$ for $12 \mathrm{~h}$.

Subsequently, $1.18 \mathrm{~mL}$ of $20 \mathrm{mg} \mathrm{mL} \mathrm{m}^{-1} \mathrm{H}_{2} \mathrm{PtCl}_{6} \cdot 6 \mathrm{H}_{2} \mathrm{O}$ aqueous solutions and $20 \mathrm{~mL} \mathrm{EG}$ were added to another flask. The $\mathrm{pH}$ of the system was adjusted to $\sim 9$ by the $5 \mathrm{wt} \%$ $\mathrm{KOH} / \mathrm{EG}$ solution. The obtained RuIr/C powders ( $80 \mathrm{mg}$ ) were introduced into the flask 
and the mixture was stirred for $4 \mathrm{~h}$ at $120^{\circ} \mathrm{C}$. Subsequently, the resulting powders were collected by filtration and then washed with deionized water until no chloride anion in the filtrate, and followed by drying in air at $60^{\circ} \mathrm{C}$ for $12 \mathrm{~h}$. The Pt@RuIr/C catalyst was obtained. For comparing, PtRuIr/C (Atom ratio Pt : Ru : Ir $=3: 3: 1$ ) were synthesized by using the same method for preparing RuIr/C.

\section{Measurements}

The catalysts were characterized by recording their XRD patterns on a Shimadzu XD-3A (Japan), using filtered $\mathrm{Cu}-\mathrm{Ka}$ radiation. All XRD patterns were analyzed using Jade 7.5 of Material Data, Inc. (MDI): peak profiles of individual reflections were obtained by a non-linear least-square fit of the $\mathrm{Cu} \mathrm{Ka}$ corrected data. TEM-measurements were carried out on a Tecnai G220 S-TWIN (FEI Company); the acceleration voltage was $200 \mathrm{kV}$. The Energy-Dispersive X-ray spectroscopy (EDX) analysis was performed in an analyzer associated with TEM.

The electrochemical measurements of the catalysts were performed using an electrochemical work station (Potentiostat/Galvanostat RST 3000). A typical threeelectrode electrochemical cell was used for the measurements. The counter and reference electrodes were a platinum wire and an $\mathrm{Ag} / \mathrm{AgCl}(3 \mathrm{M} \mathrm{KCl})$, respectively. The working electrode was a Glassy Carbon disc (GC, $5 \mathrm{~mm}$ in diameter). The thin-film electrode was prepared as follows: $5 \mathrm{mg}$ of the catalyst was dispersed ultrasonically in $1 \mathrm{~mL}$ Nafion $囚 /$ ethanol ( $0.25 \%$ Nafion $囚$ ) for 15 min. $8 \mu \mathrm{L}$ of the dispersion was transferred onto the GC disc using a pipette, and then dried in air.

\section{Results and Discussion}

Catalysts of various compositions were examined by XRD. XRD patterns of the RuIr/C, Pt@RuIr/C, and PtRuIr/C are shown in Figure 1. The diffraction patterns between $32^{\circ}$ and $70^{\circ}$ are enlarged in the inset of Figure 1 . The first peak located at about $24.8^{\circ}$ in all the $\mathrm{XRD}$ patterns is associated to the carbon support. In the case of $\mathrm{RuIr} / \mathrm{C}$ and $\mathrm{PtRuIr} / \mathrm{C}$ sample, only a broad peak appears at approximately $2 \theta=45^{\circ}$, indicating that these samples are amorphous. The diffraction peak of PtRuIr/C is shifted to higher $2 \theta$ values with respect to the corresponding peaks in the RuIr/C sample. The shift of the peaks to higher angles reveals the alloy formation between Pt and RuIr. After Pt atoms deposited on the RuIr alloy nanoparticles in the sample of Pt@RuIr/C, XRD pattern has significant changes. This phenomenon suggests that Pt atoms modify on the surface of RuIr nanoparticles, rather than are alloyed with RuIr nanoparticles. 


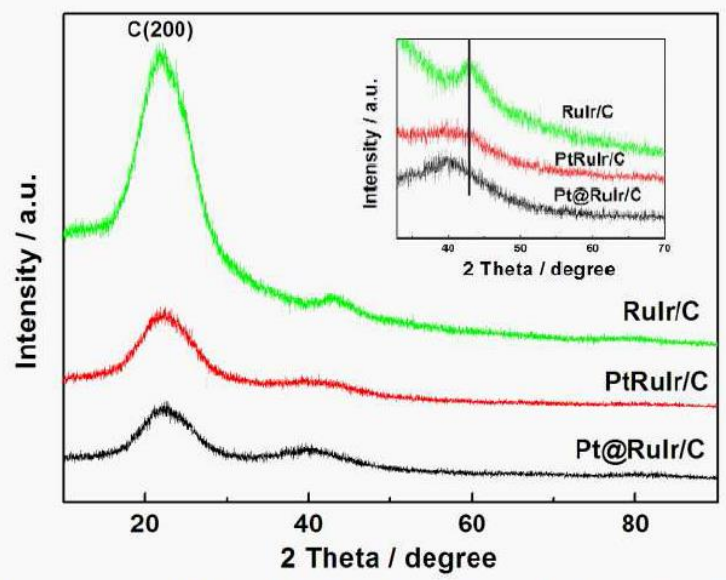

Figure 1. XRD patterns of RuIr/C, PtRuIr/C, and Pt@RuIr/C catalysts. The inset shows enlargement peaks from 32 to 70 degree of $2 \theta$.

The morphology of the catalyst was also investigated by TEM. The TEM images and corresponding Selected Area Diffraction (SAD) patterns of RuIr/C (a) and Pt@RuIr/C (b) are presented in Figure 2. RuIr and Pt@RuIr nanoparticles are shown to be well- dispersed onto the carbon support (Figure 2). The sizes of RuIr nanoparticles were in the range of 1-3 $\mathrm{nm}$ with an average diameter of $1.8 \mathrm{~nm}$. The particle sizes of the Pt@RuIr samples increased compared with RuIr. The size distribution of the particles exhibited a similar magnitude of ranges from minimum to maximum particle sizes in the samples, indicating that the reduced Pt atoms were uniformly deposited on the RuIr nanoparticles during the nucleation and growth processes. In addition, the diffused ring in the SAD pattern reconfirmed that the alloy powders are amorphous. The EDX for the samples are also shown in the inset. The EDS analysis revealed that the chemical compositions and metal loadings of the catalysts are in good agreement with the amounts of their precursors, indicating that all of the metal precursors had been completely reduced and there was no significant loss of metal nanoparticles during the synthesis procedure.

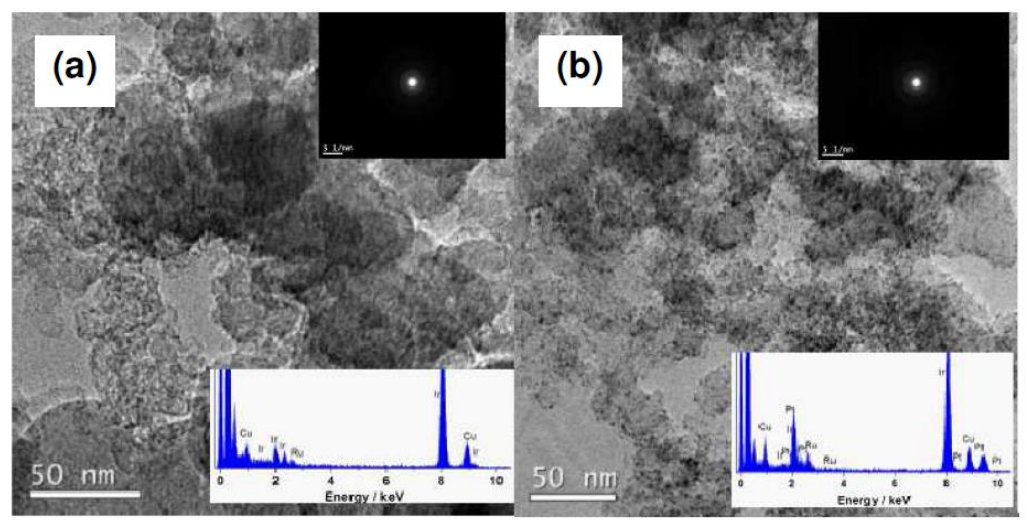

Figure 2. TEM images of RuIr/C (a) and Pt@RuIr/C (b) catalysts. The inset shows the corresponding SAD and EDS patterns of RuIr/C and Pt@RuIr/C catalysts. 


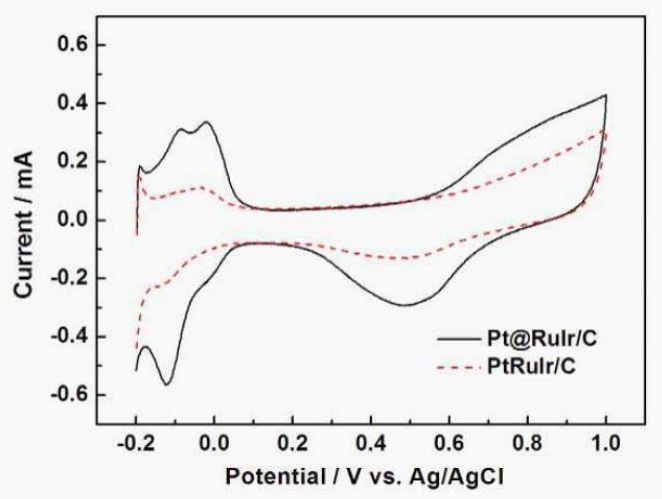

Figure 3. Cyclic voltammograms of Pt $@$ RuIr/C and PtRuIr/C electrocatalysts in $0.5 \mathrm{M}$ $\mathrm{H}_{2} \mathrm{SO}_{4}$ at $50 \mathrm{mV} \mathrm{s}^{-1}$ at room temperature.

In order to investigate the surface structures of the Pt@RuIr/C samples, CV measurements were carried out in $0.5 \mathrm{M} \mathrm{H}_{2} \mathrm{SO}_{4}$. The $\mathrm{CV}$ results are shown in Figure 3. PtRuIr/C exhibits a CV curve that is typical of the Ir surface, while Pt@RuIr/C samples exhibit a gradual change toward the CV curve of Pt. Pt@RuIr/C exhibits a curve that is almost identical to that of Pt, indicating that the surface of RuIr nanoparticles is completely covered by $\mathrm{Pt}$, and the Pt overlayer is sufficiently thick for covering the underlying Ir and shows the CV characteristics of Pt@RuIr/C.

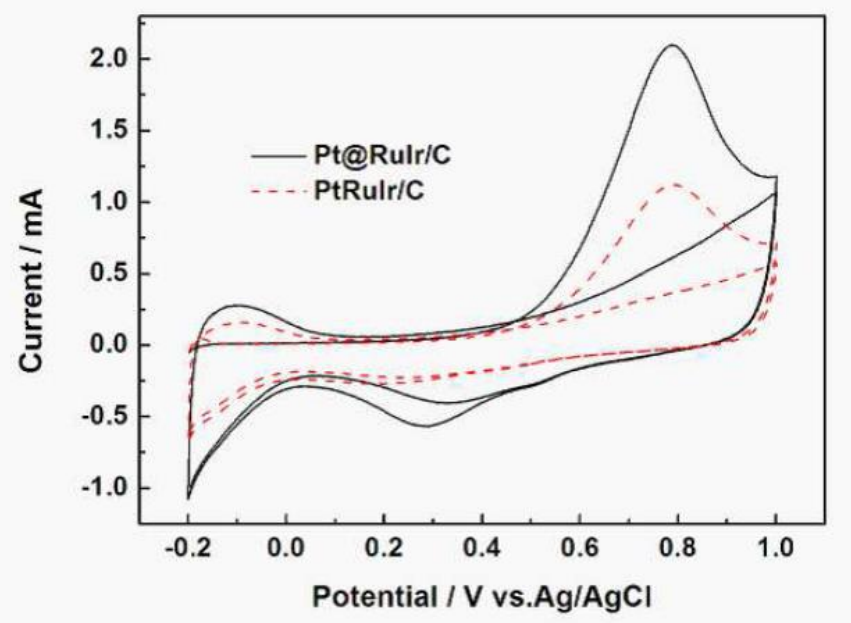

Figure 4. CO stripping voltammograms of Pt@RuIr/C and PtRuIr/C catalysts.

CO stripping is a key parameter for electrocatalysts used in DMFCs, in that the eletrocatalyst can reduce or avoid strongly adsorbed $\mathrm{CO}$ species formed on the surface or favor $\mathrm{CO}$ oxidation at low potentials. $\mathrm{CO}$ oxidation, i.e. $\mathrm{CO}$ stripping, can provide valuable information about the nature of the samples. The capability of $\mathrm{CO}$ oxidation for $\mathrm{Pt} @ \mathrm{RuIr} / \mathrm{C}$ and PtRuIr/C catalysts were evaluated by CO stripping analysis which were carried out by cyclic voltammogramms in $0.5 \mathrm{M} \mathrm{H}_{2} \mathrm{SO}_{4}$ at a scan rate of $50 \mathrm{mV} \mathrm{s}^{-1}$ at room temperature, and results are presented in Figure 4. It can be observed that the onset potential of CO oxidation on Pt@RuIr/C shifts to lower potentials compared to that of 
PtRuIr/C, and their onset potentials for Pt@RuIr/C and PtRuIr/C are at about $+0.48 \mathrm{~V}$ and $+0.51 \mathrm{~V} v$ s. $\mathrm{Ag} / \mathrm{AgCl}$, respectively.

The Electrochemically Active-Specific Area (SEAS) of the catalyst was calculated using the equation ${ }^{15-1}$

$$
S_{E A S}=Q_{C O} / 484^{*}\left(\mu \mathrm{C} \mathrm{cm}^{-2}\right) / w
$$

where $S$ EAS is the electrochemical active surface area of different catalysts, $Q C O$ is the charge for $\mathrm{CO}$ desorption electro-oxidation in microcoulomb $(\mu \mathrm{C}), 484$ is the charge required to oxidize a monolayer of $\mathrm{CO}$ on the catalyst in $\mu \mathrm{C} \mathrm{cm}^{-2}$ and $w$ is the metal loading, respectively. The results of $S E A S$ are 266 and $153 \mathrm{~m}^{2} \mathrm{~g}^{-1}$ precious metal ${ }^{-1}$, for $\mathrm{Pt} @ \mathrm{RuIr} / \mathrm{C}$ and PtRuIr/C, respectively. Here the active surface area of $266 \mathrm{~m}^{2} \mathrm{~g}^{-1}$ for the asprepared core-shell Pt@RuIr catalyst, was higher than the theoretical value obtained by Markovic et al. ${ }^{18}$ for a (111) Pt monolayer (empty shell) which is estimated to be ca. $205 \mathrm{~m}^{2}$ $\mathrm{g}^{-1}$ considering 1.51015 atoms of $\mathrm{Pt} \mathrm{cm}^{-2}$ and could be due to experimental errors.

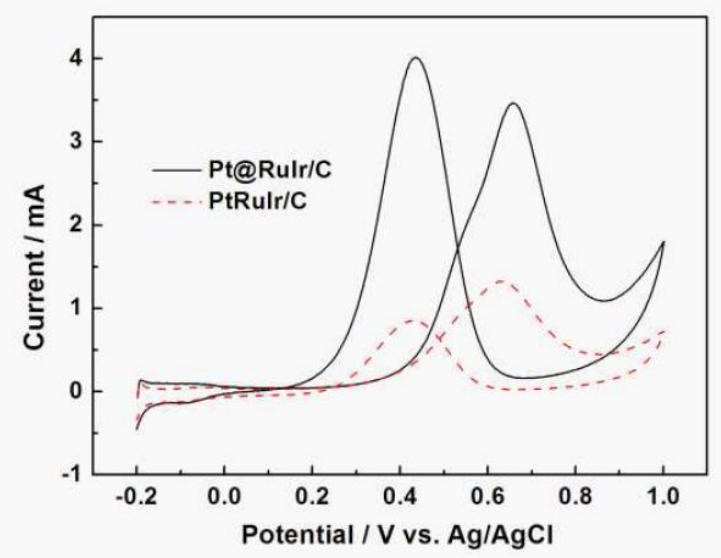

Figure 5. Cyclic voltammograms of $\mathrm{Pt} @ \mathrm{RuIr} / \mathrm{C}$ and $\mathrm{PtRuIr} / \mathrm{C}$ catalysts in $0.5 \mathrm{M} \mathrm{CH}_{3} \mathrm{OH}$ $+0.5 \mathrm{M} \mathrm{H}_{2} \mathrm{SO}_{4}$ electrolyte at $50 \mathrm{mV} \mathrm{s}^{-1}$ at room temperature.

Activity of the newly prepared catalysts toward anodic oxidation was also tested in methanol solution with sulfuric acid electrolyte using CV. Figure 5 shows CVs of the $\mathrm{Pt} @ \mathrm{RuIr} / \mathrm{C}$ and PtRuIr/C electrodes for methanol electro-oxidation in $0.5 \mathrm{M} \mathrm{CH}_{3} \mathrm{OH}+0.5$ $\mathrm{M} \mathrm{H}_{2} \mathrm{SO}_{4}$ at $25^{\circ} \mathrm{C}$. The Pt@RuIr/C shows superior catalytic activity to PtRuIr/C, i.e. ' lower onset potential and higher oxidation current density. The mass activity value of $\mathrm{Pt} @ \mathrm{RuIr} / \mathrm{C}$ catalyst is $0.433 \mathrm{~A} \mathrm{mg}$ precious $\mathrm{metal}^{-1}$, which is about 2.6 times higher than that of PtRuIr/C catalyst ( $0.167 \mathrm{~A}$ mg precious metal Chronoamperometric experiments are carried out to observe the stability and possible poisoning of the catalysts under short time continuous operation. 


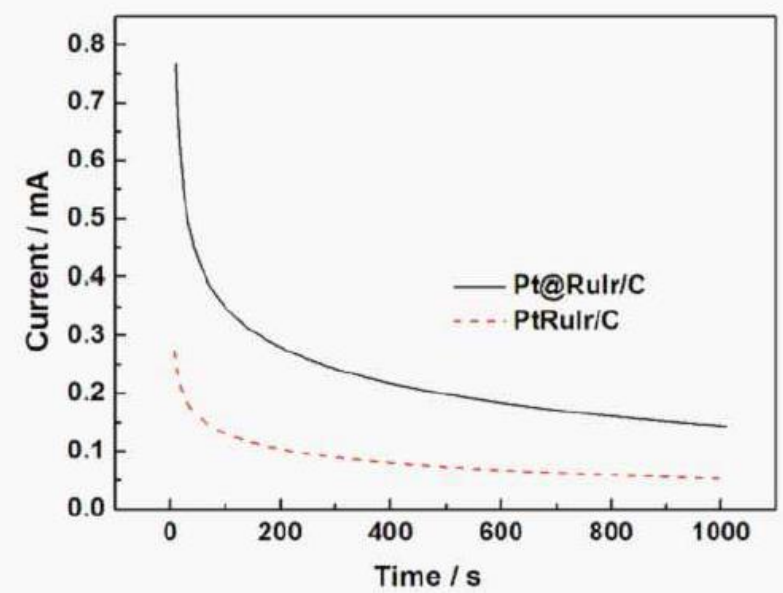

Figure 6. Chronoamperometric curves of $0.5 \mathrm{M} \mathrm{CH}_{3} \mathrm{OH}$ in $0.5 \mathrm{M} \mathrm{H}_{2} \mathrm{SO}_{4}$ solution on $\mathrm{Pt} @ \mathrm{RuIr} / \mathrm{C}$ and PtRuIr/C electrodes for $1,000 \mathrm{~s}$; fixed potential $=+0.6 \mathrm{~V}$ vs. $\mathrm{Ag} / \mathrm{AgCl}$, rotation speed $=300 \mathrm{rpm}$.

Figure 6 shows such typical $i-t$ plots with the current normalized to the initial current. For each catalyst, the decay in the methanol oxidation is different. Figure 6 is clearly shown that the Pt@RuIr/C composite electrode is more stable than the PtRuIr/C electrode when the electrodes are compared under identical experimental conditions. It can be observed that the currents of the Pt@RuIr/C and PtRuIr/C catalysts at 1,000 s are 0.145 and $0.053 \mathrm{~mA}$. It is clearly shown in Figure 6 that the deceasing rate of current density with time for Pt@RuIr/C is much slower than that of PtRuIr/C, which indicates that Pt@RuIr/C has better anti-poisoning ability. The above results demonstrate that the electrocatalytic stability of the Pt@RuIr/C catalyst for methanol oxidation is much higher than that of the PtRuIr/C catalyst.

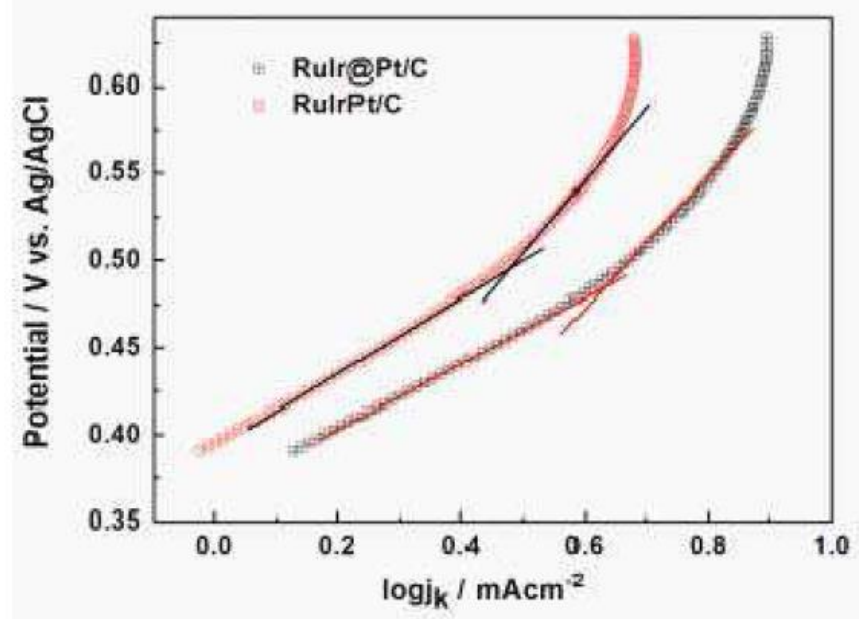

Figure 7. Tafel plots of methanol oxidation on Pt@RuIr/C and PtRuIr/C catalysts in 0.5 $\mathrm{M} \mathrm{CH}_{3} \mathrm{OH}+0.5 \mathrm{M} \mathrm{H}_{2} \mathrm{SO}_{4}$ solution under $\mathrm{N}_{2}$ atmosphere. Scan rate: $5 \mathrm{mV} \mathrm{s}^{-1}$.

Tafel plots for the methanol oxidation on the Pt@RuIr/C and PtRuIr/C catalysts derived from the Linear Sweep Voltammograms in $0.5 \mathrm{M} \mathrm{H}_{2} \mathrm{SO}_{4}$ solution $+0.5 \mathrm{M} \mathrm{CH}_{3} \mathrm{OH}$ at a 
scan rate of $5 \mathrm{mV} \mathrm{s}^{-1}$, as shown in Figure 7. Each plot can be fitted and divided into two linear regions according to the change of Tafel slopes. On the Pt@RuIr/C, the Tafel slopes values are comparable with those on the PtRuIr/C, indicating that the MOR mechanism on Pt@RuIr/C remains the same as on PtRuIr/C. The difference in Tafel slope values at low and high overpotentials may be associated to a possible change of reaction mechanism(s) or at least to a change in the Rate- Determining Step (RDS) in the potential range employed.

\section{Conclusions}

In summary, we have developed a very general strategy to prepare carbon supported coreshell structure Pt@RuIr NPs with intimate contact between Pt and RuIr. The asprepared structures were investigated using XRD, TEM and electrochemical techniques. The electrocatalyst activities were tested using the methanol oxidation as "probe reactions". Core-shell catalysts with Pt on the surface of RuIr nanoparticles exhibited higher catalytic activity than PtRuIr/C, as a result of improved Pt utilization. This work further confirms that catalytic activity of Pt catalyst can indeed be improved through controlling not only the metal size and shape but also its structure. These nanostructures have obvious structural advantages in terms of unique catalytic properties, simple and clean processing, and saving precious metals, which show their great potential for use in DMFCs technologies.

\section{Acknowledgments}

The authors would like to thank the National Natural Science Foundation of China (21163018), the National Science Foundation for Post-doctoral Scientists of China (20110490847), Guangdong Key Lab for Fuel Cell Technology and the South African NRF (SFP20110918000027143) for financially supporting this work. 


\section{References}

1. S. K. Kamarudin, W. R. W. DaUD, S. L. Ho and U. A. Hasran, J. Power Sources, 163, 743 (2007).

2. M. K. Debe, Nature, 486, 43 (2012).

3. E. Antolini, Mater. Chem. Phys., 78, 563 (2003).

4. Y. Liang, H. Zhang, H. Zhong, X. Zhu, Z. Tian, D. Xu, and B. Yi, J. Catal., 238, 468 (2006).

5. S. J. Hwang, S. J. Yoo. T.-Y. Jeon, K.-S. Lee, T.- H. Lim, Y.-E. Sung, and S.-K. Kim, Chem. Commun., 46, 8401 (2010).

6. S. Sui, L. Ma, and Y. Zhai, J. Power Sources, 196, 5416 (2011).

7. S. Liao, K. A. Holmes, H. Tsaprailis, and V. I. Birss, J. Am. Chem. Soc., 128, 3504 (2006).

8. D. Geng, D. Matsuki, J. Wang, T. Kawaguchi, W. Sugimoto and Y. Takasu, J. Electrochem. Soc., 156, B397 (2009).

9. X. Zhang, H. Wang, J. Key, V. Linkov, S. Ji, X. Wang and R. Wang, $J$. Electrochem. Soc., 159, B270 (2012).

10. R. Wang, Z. Zhang, H. Wang and Z. Lei, Electrochem. Commun., 11, 1089 (2009).

11. R. Wang, H. Li, S. Ji, H. Wang and Z. Lei, Electrochim. Acta, 55, 1519 (2010).

12. A. Molnar, G. V. Smith and M. Bartok, Adv. Catal. 36, 329 (1989).

13. X. B. Zhang, J. M. Yan, S. Han, H. Shioyama and Q. Xu, J. Am. Chem. Soc., 131, 2778 (2009).

14. H. Wang, X. T. Zhang, R. F. Wang, S. Ji, W. Wang, Q. Z. Wang and Z. Q. Lei, J. Power Sources, 196, 8000 (2011).

15. C. Zhou, H. Wang, F. Peng, J. Liang, H. Yu and J. Yang, Langmuir, 25, 7711 (2009).

16. Y. Zhao, X. Yang, J. Tian, F. Wang and L. Zhan, J. Power Sources, 195, 4634 (2010).

17. Z. Wang, G. Yin, J. Zhang, Y. Sun and P. Shi, Electrochim. Acta, 51, 5691 (2006).

18. N. M. Markovic, B. N. Grgur and P. N. Ross, J. Phys. Chem. B, 101(27), 5405 (1997). 